\title{
Pääkirjoitus
}

\section{Enemmän markkinointia ja vaikuttavuuden näyttämistä, vähemmän valittamista ja sisäänpäinkääntyneisyyttä?}

STKS järjesti yhdessä Suomen kirjastoseuran ja Helsingin yliopiston kirjaston kanssa IFLA Global Vision -työpajan Helsingissä 20.9.2017. IFLA on järjestänyt näitä ideointi-työpajoja ympäri maailmaa tänä vuonna, tarkoituksenaan rakentaa koko kirjastokentälle yhteinen visio.

Työpajassa mietittiin kirjastojen tärkeimpiä arvoja sekä sitä, missä kirjastot ovat hyviä. Pienryhmissä ideoitiin myös mitä kirjastojen pitäisi tehdä enemmän ja mitä olisi parempi vähentää. Lopuksi äänestettiin niin, että saatiin jokaiseen kysymykseen viisi kärkivastausta. Äänestyksessä suosituimmiksi nousivat seuraavat ideat. Mitä niistä sinä pidät tärkeinä?

\begin{tabular}{|l|l|l|l|}
\hline $\begin{array}{l}\text { MITKÄ OVAT } \\
\text { KIRJASTON } \\
\text { TÄRKEIM- } \\
\text { MÄT ARVOT? }\end{array}$ & $\begin{array}{l}\text { MISSÄ } \\
\text { KIRJASTOT } \\
\text { OVAT HYVIÄ? }\end{array}$ & $\begin{array}{l}\text { MITÄ } \\
\text { KIRJASTOJEN } \\
\text { PITÄISI TEHDÄ } \\
\text { ENEMMÄN? }\end{array}$ & $\begin{array}{l}\text { MITÄ } \\
\text { KIRJASTOJEN } \\
\text { PITÄISI TEHDÄ } \\
\text { VÄHEMMÄN? }\end{array}$ \\
\hline AVOIMUUS & $\begin{array}{l}\text { ASIAKAS- } \\
\text { PALVELU }\end{array}$ & $\begin{array}{l}\text { MARKKI- } \\
\text { NOINTI }\end{array}$ & $\begin{array}{l}\text { PÄÄLLEK- } \\
\text { KÄISTÄ TYÖTÄ }\end{array}$ \\
\hline $\begin{array}{l}\text { TIEDON } \\
\text { LUOTET- } \\
\text { TAVUUS }\end{array}$ & AVOIMUUS & $\begin{array}{l}\text { VERKOS- } \\
\text { TOITUMINEN }\end{array}$ & $\begin{array}{l}\text { LUKKIUTUA } \\
\text { VANHAAN } \\
\text { OSAAMISEEN }\end{array}$ \\
\hline $\begin{array}{l}\text { TASA-ARVON } \\
\text { EDISTÄMINEN }\end{array}$ & $\begin{array}{l}\text { LÄHES- } \\
\text { TYTTÄVYYS }\end{array}$ & $\begin{array}{l}\text { VAIKUTTA- } \\
\text { VUUDEN } \\
\text { NÄYTTÄMINEN }\end{array}$ & $\begin{array}{l}\text { SISÄÄNPÄIN } \\
\text { KÄÄNTY- } \\
\text { NEISYYTTÄ }\end{array}$ \\
\hline $\begin{array}{l}\text { MAKSUT- } \\
\text { TOMUUS }\end{array}$ & $\begin{array}{l}\text { KIRJASTO- } \\
\text { VERKON } \\
\text { KATTAVUUS }\end{array}$ & ROHKEUS & VALITTAMISTA \\
\hline $\begin{array}{l}\text { SIVISTYS } \\
\text { JA TAIDE } \\
\text { / YHTEIS- } \\
\text { KUNNALLINEN } \\
\text { VASTUUL- } \\
\text { LISUUS }\end{array}$ & $\begin{array}{l}\text { AINEISTON } \\
\text { HALLINTA }\end{array}$ & $\begin{array}{l}\text { SISÄLTÖJEN } \\
\text { AVAAMINEN }\end{array}$ & $\begin{array}{l}\text { ESTOJA JA } \\
\text { RAJOITUKSIA }\end{array}$ \\
\hline
\end{tabular}


Ainakin yhdessä pöydässä toivottiin, että STKS ja Suomen kirjastoseura yhdistyisivät. Muissa Pohjoismaissa on yhteinen seura tieteellisille, erikois- ja yleisille kirjastoille. Ajoittain tätä on pohdittukin jo ainemmin. Mitä mieltä sinä olet, onko aika seurojen yhdistymiselle NYT?

globalvision.ifla.org

\#iflaGlobalVision

Johanna Lahikainen 